\title{
Integration of Finite Element Analysis, 3D Printing and Biopolymers to Enhance Research in Orthopaedics
}

\author{
D. Yadav*, R.K. Garg ${ }^{\dagger}$ \\ Department of Mechanical Engineering, Deenbandhu Chhotu Ram University of Science and Technology, \\ Murthal, Haryana, India
}

(Received 10 January 2021; revised manuscript received 24 March 2021; published online 09 April 2021)

\begin{abstract}
FEA is a very powerful tool for biomechanically examining orthopaedic trauma. In order to improve the design, screening, estimation and treatment of orthopaedics, finite element (FE) simulations can evaluate thousands of variables effectively and reliably (including implant variance, surgical procedures and different diseases). In addition, FEA can be used to evaluate and fix issues or failures retrospectively in order to deter similar injuries in the future. FEA will potentially be used in a time-efficient and cost-effective assessment of implants, therapies and techniques. This work includes a description of the development of FE models, 3D printing techniques used in orthopaedics along with the evolution of biopolymers in medical industry. For FE models, geometry of interest must be developed, the material properties of virtual tissues measured and the numerical solver correctly used to construct an effective solution and to define the field variables. The purpose of this work is to introduce the reader to the effectiveness of integrating the FEA in orthopaedics application with 3D printing and biopolymers and to provide a brief description of the modelling process. Also FEA is applied for designing LCP for Femur bone. From this work, it can be concluded that the integration of $\mathrm{FE}$ analysis and 3D printable biopolymers with 3D printing in orthopaedics research can provide considerable new information to make technically more appropriate decisions and highly beneficial from society point of view.
\end{abstract}

Keywords: FEA, 3D printing, Biopolymers, Implants, Modeling.

DOI: 10.21272/jnep.13(2).02005

PACS numbers: 87.85.J, 82.35.Pq

\section{FINITE ELEMENT ANALYSIS}

FEM is basically a numerical solution algorithm which apart from orthopaedics is effectively utilized in biology, engineering, mathematics and physics. Further, Finite element analysis (FEA) is used to evaluate representative geometry in the virtual space which is a type of silico simulation. Both the terms (FEA and FEM) are used interchangeably for solving complex problems which are not possible to be solved effectively using analytical methods alone. FEA is taken in use to search modifiable parameters where problems arise which helps in improving future interventions. In orthopaedics, the applications of both vary from problem to problem. It is generally observed that the algorithm followed is similar, which consists of:

1. Creation of geometry; 2. Geometry meshing; 3. Assignment of material properties; 4 . Defining boundary conditions and interactions; 5 . Forces application; 6 . Simulation; 7. Visualization of results; 8 . Validation of FE simulation results and Geometry creation.

CAD software can be an alternative method of generating geometry natively. Therefore, to analyze the particular behavior at the tissue and cellular level, parameterized axisymmetric models may be tailored.

As per the finite element model geometry, the domain must be discretized into a mesh of connected elements. The geometrics used and the objectives of models are the base of number and type of elements. FE mesh with certain nodes and element connectivity are made out of solid geometric representation using mesh- ing algorithm. Solution accuracy may be improved by enhancing mesh density but it in turn will increase efforts put in computation and solution time. Also meshes may be biased accordingly to enhance densities at certain areas of interest.

Actual and similar tissue testing is done to determine the material properties. In orthopaedics the material models used for FEA vary in complexity, from simple linear isotropic to complex multiphasic visco and hyper elastic materials. The main element on which material complexity depends is anatomy and physiology of interest and computational resources available. It can be seen that the more complex material behavior will have high computational cost and longer time duration for the solutions.

\section{3D PRINTABLE BIOPOLYMERS}

FEM is basically a numerical solution algorithm which apart from orthopaedics is effectively utilized in biology, engineering, mathematics and physics. Further, Finite element analysis (FEA) is used to evaluate representative geometry in the virtual space which is a type of silico simulation. Both the terms (FEA and FEM) are used interchangeably for solving complex problems which are not possible to be solved effectively using analytical methods alone. Biopolymer is a long chain of covalently attached monomers. Depending upon the nature of monomers biopolymers are classified as homo biopolymers and co biopolymers. If the repeating monomer is the same throughout the chain

\footnotetext{
*Dineshkoslia91@gmail.com

$\dagger$ drrkgarg.me@dcrustm.org

The results were presented at the International Conference on Multifunctional Nanomaterials (ICMN2020)
} 
then it is known as homo biopolymers otherwise co biopolymers. The type of linkage and bonding between the monomers decide the physical and mechanical characteristics of biopolymers. Temperature directly affects the properties of the polymers. Biodegradable polymers must be stable over body temperature [1].

About 86 percent of biomaterials for fabrication of orthopedic implants are provided by $3 \mathrm{D}$ printable biodegradable biopolymers. Depending upon the source of origin, these can be classified as natural and synthetic biopolymers. Typical polysaccharides like (starch, alginate, chitosan, etc.) and proteins are natural biopolymers. However, due to its high physiological activity, repellent, unpredictable degradation levels and weak mechanical properties, the applications are significantly limited. However, the design and control properties of synthetic biopolymers are stronger than natural biopolymers. The degradation and decay of bioresorbable polymers are approximately equal to the rate of regeneration of host bone tissues. The orthopaedic industry mostly used synthetic biopolymers for the fabrication of implants as these materials offer the same characteristics as that of host bone. Based on the evolution pattern these materials are classified in first and secondgeneration biopolymers. As the 3DP techniques grow rapidly in the field of orthopaedics for the fabrication of implants, surgical guides, nails, bone plates, bolt, screw and scaffolds etc. it is very necessary to emphasize and characterization of 3D printable biopolymers. 3DP with biopolymers covers 86 percent of orthopaedic industry. Fig. 1 shows the percentage-wise biopolymers used in orthopaedics.

\section{Bio-Polymer Used Percentage in Orthopaedics Industry}

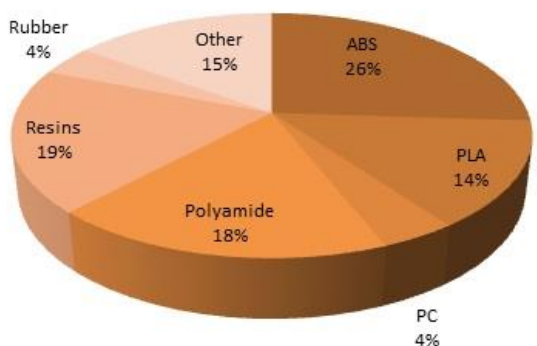

Fig. 1 - Percentage wise distribution of biopolymers in orthopaedics

\subsection{First Generation Biopolymers}

As per Hench classification, the biopolymers which have less foreign particle reactions with the body and minimum immune response are known as firstgeneration biopolymers. The only condition to obey for the first generation biopolymers is that the physical characteristics of the materials must be the same with the host tissue, which is substituted by the material with minimum toxicity. Silicon rubber, poly-methylmethacrylate (PMMA), polyethylene or UHMWPE, acrylic resins, and polypropylene (PP) are some firstgeneration biopolymers. As per the 3D printing point of view, UHMWPE and PMMA are the first generation biopolymers that are used till now in orthopaedic industry.

\subsection{PMMA}

The use of PMMA plastic acrylic bone cement by Charnley was introduced in the 70 s (Leong and $\mathrm{Lu}$ 2004). Mixing of liquid monomer and the powdered polymer is used for the formulation of PMMA cement by an in-vivo heat-releasing reaction in a temperature range of $48-56{ }^{\circ} \mathrm{C}$. The content of the Monomer differs significantly in various available preparations, while the powdered content usually includes a polymer, accelerators, different molecular weight copolymers, initiators, and antibiotics. To reduce the infection risk and increase X-ray visualization, antibiotics and barium are added respectively. PMMA is available in both low and high viscosity. Its modulus of elasticity is lying close to both cortical and cancellous bones. Due to its viscoelastic behaviors, high stiffness, and stress relaxation property it mostly acts as a filler material.

First-generation polymer-based biomaterials can be shaped as per patient bone anatomy using a $3 \mathrm{D}$ printing technique. Although in the case of the bone plate, the rigidity and lack of ductility of first-generation materials do not allow the surgeon during operation to make the last bending to adapt the patient's bone anatomy. A typical characteristic of polymer-based biomaterials of the first generation is the adsorption of a coating of different unspecific proteins on the surface of the implant which results in unspecific cellular signals. The effect is that on the surface of the material a layer of fibrous tissue develops, and over time, such a fibrous tissue encloses the implant. One of the important factors in bio-polymer based biomaterials of the second generation was the growth of bioactive interfaces, which produce a specific biological response and avoid any fibrous layer formation.

\section{SECOND GENERATION BIOPOLYMERS}

The second generation of biopolymers advanced from 1980 to 2000 . These biomaterials improved the biological reactions and tissue binding by interacting with the biological environment. Bioactivity is the influence of chemicals on cells with specific responses and acts to steer or disable them. Mineralization of bone tissue and the implant is an important mechanism for increasing bioactivity in bone recovery and fixation applications respectively. The in-vivo deposition of the HA coating on the surface of bioactive biopolymers helps in bone binding, recovery and regeneration. In 1960, Kulkarni et al. presented the idea of a bioresorbable material. The resorbable biopolymers like polyglycolide (PGA), polylactides (PLA), polydioxanones (PDS), poly(2-hydroxyl-methacrylates), polyhydroxybenzin (PHB), (ABS), (PEEK), poly(2-hydroxyethylmethacrylate) (PHEMA) and other hydrogels with a controlled rate of resorption and disintegration lies in the category of $2^{\text {nd }}$ generation bio-polymers. At present these materials are used in many orthopaedic applications like bone fracture fixation, nails, plates, screws, rod and pin production. Some of the important $2^{\text {nd }}$ generation biopolymers are discussed below.

\subsection{Polylactic Acid (PLA)}

PLA is extensively utilized as a bioresorbable biopolymer in orthopaedics from the last fifty years [2, 3]. 
In 1780, Scheele noticed the use of PLA based sutures and rods for recuperation jaw fractures in dogs. After that these kinds of many consequences have been recorded in the diverse medicinal field [4]. In 1988, Cargill Inc., USA, instigated a venture to broaden PLA to set up new starch processed invention [5]. PLA is taken into consideration as a new kind of polymer that fashioned from the $100 \%$ natural renewable sources including corn. It is divided into two principal classes i.e., LPLA (in the main crystalline) and DL-PLA (in the main amorphous) that used in orthopaedics [6]. L-PLA crystalline is hydrolysis resistant at the same time as DLPLA amorphous is hydrolysis sensitive [7]. Therefore, PLA is frequently used because the copolymer of L-PLA and DL-PLA monomers. Along with these, PLA offers biocompatibility with the bones and offers similar mechanical properties as that of bones.

\subsection{Polygalactic acid (PGA)}

PGA is mainly used as biodegradable stitches with strong crystallinity, weak solubility and high melting point. In 1962, Dexon is the first biodegradable suture thread produced by the US-based Cyanamide company [8]. Due to its hydrophilism nature, the degradation value of PGA is overwhelming. In general, the strength of the implant decreases to 50 percent after implantation and to 90 percent after 28 days. PLGA is also commonly used as a PGA and PLA copolymer in clinical procedures in orthopaedics industry. Polyglactin 910 and vicryl are widely used PLGA-formulated fibers. The thing that degrades PGA is hydroxyl acetic acid, which is either released into the kidney or metabolized through the liver media with carbon dioxide and water as the last products to cease. The key advantage of the bio-PGA is that it is no longer toxic, aggregated and biodegraded [9-11].

\subsection{Poly ether Ketone (PEEK)}

It is an aromatic molecular chain bound by ketone and ether functional groups. PEEK biopolymer is mostly used for the fabrication of orthopaedics implants, spinal implants, fracture fixation plates, and complete joint replacement. It is a radiolucent biopolymer that allows easy X-ray, CT, or MRI assessment of surgical sites [12]. PEEK biomaterial is used for the fabrication of a wide variety of applications due to their high mechanical strength and corrosion impermeability. When part of an unfilled environment, it may be used for added substances such as carbon or coated wires or hydroxyapatite, for example, for bioactive added substances. The Young's modulus of filled PEEK composites biomaterials have higher than that of Titanium alloy, but in its original state PEEK has only $4 \mathrm{GPa}$ Young's modulus which is very less as compare to $\mathrm{Ti}$ alloy [13]. 30 percent addition of carbon fibers raises the young modulus of PEEK biopolymer by $20 \mathrm{GPa}$ [14]. PEEK biopolymer based orthopaedics implants are the best option to replace the metal implants.

\subsection{D Printing Techniques and Orthopaedics}

Fused Deposition Modeling (FDM) uses PLA, ABS, Nylon, PLGA, PCL and PEEK. It works on the princi- ple of wire extrusion of $3 \mathrm{D}$ printable thermobiomaterials. It has various advantages like; wide range of geometries, complex structure, affordable prices, timeless manufacturing and the material used is readily available. Due to these positives, it has various applications like, it is used in orthodontic implants, scaffolds and surgical guides, surgical anatomical models for perioperative planning and tailoring patientspecific orthopaedic implants. On the other hand, it has some limitations too; the products have shorter life span, poor surface finish, and the inadequacy of material availability.

Secondly, the stereolithography (SLA) uses materials like, PCL, PPF and PDL. It works on the principle of polymerization of photocurable liquid resin initiated by laser. Its advantages also include the better surface finish and high dimensional accuracy. It is used in making personalized scaffolds, drug-loaded scaffolds and implantable devices. Its only drawback is the limited material availability.

The third technique is the Digital light projection (DLP) which works on the principle of UV rays solidification of photosensitive material. The material used in the technique is wax photosensitive resins which are used in making complex organ structures like ear auricle, cardiovascular implants and various other implants. The high levels of accuracy, low cost of running and fast process are some of its advantages, whereas the high installation cost and the average mechanical properties are among its limitations.

Further the technique, selective laser sintering (SLS) uses PEEK/HA, PCL/HA, the polymer in powder form. It is used as dental implants, orthopaedic implants, medical equipments and scaffolds.

Lastly, Polyjet 3D printing uses ABS, rubber and polypropylene which works on the principle of UV rays solidified photosensitive material. It has high level of accuracy; it can combine with different materials and has smooth surface finish. Its application includes dental trays, orthopaedic surgical guides and hearing aids and buds. The sky-high cost and the sharp edges are among some of its drawbacks.

\subsection{FEA and Orthopaedics}

FEA of the different bones and joints like knee, ankle, elbow etc. can deliver momentous facts and figures based on that orthopaedics expert make effective clinical decision. Dr. Ferris M. Pfeiffer from University of Missouri applied the FEA for Knee joint and analyzed the stability in geometries with normal or compromised medial meniscal attachment and found that increases in stretch of the anterior cruciate ligament [15]. Lina Yan et al. 3D print the stainless steel locking compression plate implant for Tibia bone fracture fixation using FEA and also found that the designed LCP has comparatively lower Young's modulus without causing it to fail at physiological loads with superior load bearing capacity[16]

Here, FEA is also applied for designing LCP for femur bone. The designed model is then printed with PEEK biomaterial. The designed plate offers reduced Young's modulus and superior healing properties. Fig. 2 shows the stress distribution in designed LCP having four unicortical screws and eight holes. The maximum 
stress induced in the designed LCP is low which indicates it is a good design with a high factor of safety.

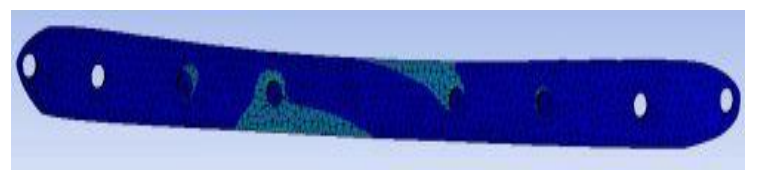

Fig. 2 - Stress distribution in LCP of Femur Bone

\section{CONCLUSIONS}

In addition to 3D bio-printing for bone and cell scaffolding, orthopedic surgeons and related specialists and scientists are enthusiastic about the usage of 3DP technology integrated with FEA to build patientspecific anatomical models, scaffolds, tools, braces, implants, orthotics and prostheses around the globe to provide a better healing environment to the patients at low cost. High strength 3D printable biopolymer based implants replaces the current metallic and ceramics based implants utilized in orthopaedics industry which reduced the cost factor for the patient and also provide a more comfortable healing process. 3DP benefits the orthopaedic industry in an economical, environmental and societal way by producing "on spot-on demand" patient specific bioresorbable implants. This integrated approach promote the 'on demand-on spot' production model and produced patient-specific orthopaedic implants which increase the rate of healing and reduced the cost, time and pain suffered by patients during healing of any orthopaedic trauma recovery also the SCM complexity in the orthopaedic industry has been reduced up to a high extent by introducing the 3DP in orthopaedics industry.

\section{ACKNOWLEDGEMENTS}

Authors are grateful to the Dr. Deepak Chhabra Maharshi Dayanand University, Rohtak for a critical reading of the manuscript and his valuable comments.

\title{
REFERENCES
}

1. W.S. Pietrzak, D.R. Sarver, M.L. Verstynen, J. Craniofac. Surg. 8 No 2, 87 (1997).

2. R. Datta, M. Henry, J. Chem. Technol. Biotechnol. 81 No 7 , 1119 (2006).

3. R.L. Shogren, W.M. Doane, D. Garlotta, J.W. Lawton, J.L. Willett, Polym. Degrad. Stabil. 79 No 3, 405 (2003).

4. R.K. Kulkarni, E.G. Moore, A.F. Hegyeli, F. Leonard, J. Biomed. Mater. Res. 5 No 3, 169 (1971).

5. E.T. Vink, K.R. Rabago, D.A. Glassner, P.R. Gruber, Polym. Degrad. Stabil. 80 No 3, 403 (2003).

6. P.B. Maurus, C.C. Kaeding, Oper. Techn Sport. Med. 12 No 3, 158 (2004)

7. A.U. Daniels, M.K. Chang, K.P. Andriano, J. Heller, J. Appl. Biomater. 1 No 1, 57 (1990).

8. A.M. Reed, D.K. Gilding, Polymer. 22 No 4, 494 (1981).

9. I. McVicar, P.V. Hatton, I.M. Brook, Initial Clinical Report. Brit. J. Oral. Max. Surg. 33 No 4, 220 (1995).

10. K.A. Athanasiou, G.G. Niederauer, C.M. Agrawal, Biomater. 17 No 2, 93 (1996).

11. J.K.F. Suh, H.W. Matthew, Biomater. 21, 2589 (2000).

12. L. Zhou, Y. Qian, Y. Zhu, H. Liu, K. Gan, J. Guo, Dental Mater. 30 No 8, e209 (2014).

13. C.S. Li, C. Vannabouathong, S. Sprague, M. Bhandari, Clinical Medicine Insights: Arthritis and Musculoskeletal Disorders (CMAMD-S20354), 8 (2015).

14. M.R. Abdullah, A. Goharian, M.R. Abdul Kadir, M.U. Wahit, J. Biomed. Mater. Res. Part A. 103 No 11, 3689 (2015).

15. F.M. Pfeiffer, J. Knee Surg. 29 No 2, 149 (2016).

16. Yan Lina, Joel Louis Lim, Jun Wei Lee, Clement Shi Hao Tia, Gavin Kane O’Neill, Desmond Y.R. Chong, Med. Biol. Eng. Comp. 58, 921 (2020).

\section{Інтеграція кінцево-елементного аналізу, 3D друку і біополімерів для розширення досліджень в області ортопедії}

\author{
D. Yadav, R.K. Garg \\ Department of Mechanical Engineering, Deenbandhu Chhotu Ram University of Science and Technology, \\ Murthal, Haryana, India
}

\begin{abstract}
Кінцево-елементний аналіз (FEA) е дуже потужним інструментом для біомеханічного дослідження ортопедичних травм. Для поліпшення дизайну, скринінгу, оцінки та лікування в ортопедії, FE моделювання може ефективно та надійно оцінити тисячі змінних (включаючи дисперсію імплантатів, хірургічні процедури та різні захворювання). Крім того, FEA може бути використаний для ощінки та усунення проблем або помилок ретроспективно, щоб уникнути подібних травм у майбутньому. FEA може потенщійно використовуватися для ефективної за часом та економічної оцінки імплантатів, терапій та методів. Робота включае опис розробки FE моделей, методів 3D друку, що використовуються в ортопедії, разом з еволюціею біополімерів у медичній промисловості. Для $\mathrm{FE}$ моделей потрібно розробити необхідну геометрію, виміряти властивості матеріалу віртуальних тканин та правильно використати числовий алгоритм вирішення для побудови ефективного рішення та визначення змінних поля. Мета роботи - ознайомити читачів з ефективністю інтеграції FEA в ортопедичних додатках з 3D друком і біополімерами та надати короткий опис процесу моделювання. Також FEA застосовуеться для розробки фіксуючих компресійних пластин (LCP) для стегнової кістки. 3 ціеї роботи можна зробити висновок, що інтеграція FEA та біополімерів з 3D друком в дослідженнях ортопедії може надати суттеву нову інформацію для прийняття технічно більш прийнятних рішень та дуже корисних з точки зору суспільства.
\end{abstract}

Ключові слова: FEA, 3D друк, Біополімери, Імплантати, Моделювання. 